УДК 657;

DOI: $10.14451 / 1.205 .494$

ББК 65.052 .5

\title{
МОДЕЛИРОВАНИЕ БИЗНЕС-ПРОЦЕССОВ НА ОСНОВЕ СОВРЕМЕННОГО ПРОГРАММНОГО ОБЕСПЕЧЕНИЯ
}

\author{
(C) 2021 Сидорова М.И. \\ доктор экономических наук, доцент, заместитель декана по научной работе \\ Факультета международных экономических отношений, \\ руководитель научно-учебной лаборатории «ANAPLAN (Analitical Planning)» \\ Финансовый университет при Правительстве Российской Федерации, Россия, Москва \\ E-mail: MISidorova@fa.ru \\ (C) 2021 Деменкова Е.А. \\ студентка Факультета международных экономических отношений, \\ Научно-учебная лаборатория «ANAPLAN (Analitical Planning)» \\ Финансовый университет при Правительстве Российской Федерации, Россия, Москва \\ E-mail: demenkova.jane@gmail.com
}

Вступая в эру цифровой экономики, каждая организация сталкивается с необходимостью изменения многих аспектов своей деятельности. Внедрение информационных технологий и ИТ-систем - важное условие сохранение конкурентоспособности организации на рынке. Моделирование бизнес-процессов предполагает решение достаточно сложных задач, которые рассмотрены в данной статье.

Ключевые слова: учет, анализ, аудит, автоматизация, моделирование, система внутреннего контроля, риск-ориентированный подход

Моделирование бизнес-процессов предполагает решение достаточно сложных задач: определение типа систем, подходящих конкретному виду и масштабу бизнеса, выбор отделов организации, цифровизация деятельности которых будет целесообразна, наконец, принятие решения о том, какую информационную систему выбрать, исходя из потребностей организации и ее финансовых возможностей. Главная цель организации в контексте цифровизации - повышение скорости, безопасности и эффективности бизнеспроцессов, а значит, затраты на внедрение каких-либо нововведений не должны превышать потенциальный экономический эффект.

Понимая важность и сложность принятия решения о выборе информационной системы для организации, проведем анализ наиболее популярных систем на предприятии. Рассмотрим такие системы, как «1C», «SAP» («SAP»CO: $\mathrm{KoH}^{-}$ троллинг») и возможности программы MS Excel.

Программные продукты компании «1С» представляют комплекс решений для автоматизации бизнес-процессов. Данные информационные системы являются наиболее популярными на российском рынке на сегодняшний день. Причиной популярности являет- ся достаточно широкий функционал, охватывающий все основные потребности компаний различных отраслей, а также сравнительно невысокая стоимость (по сравнению с продуктами компании-конкурента «SAP»). Однако в системе существует большое количество технических недостатков, постоянная настройка, перенастройка и корректировка которых обходится компаниям достаточно дорого. К тому же, далеко не все возможности для бизнес-аналитики уже представлены в системе, однако продукты «1С» могут быть совмещены со сторонним ПО. Разумеется, это требует дополнительных финансовых затрат и привлечения консультантов и программистов компаний-партнеров.

Информационные системы компании «SAP» отличаются более широким функционалом и надежностью. Бизнес-аналитика, средства визуализации данных - уже содержатся в пакетах программных продуктов (SAP Lumira - эффективная визуализация бизнес-аналитики (BI) позволяет оценивать риски, повышать эффективность, получать уникальную информацию и находить новые возможности). Производитель открыто заявляет о наличии сертификата Британского института стандартов, что под- 
тверждает сохранность данных в процессе функционирования информационной системы. Следует отметить, однако, намного более высокую стоимость решений компании «SAP», что делает их внедрение экономически целесообразным только для действительно крупных компаний.

Программные средства MS Excel следует рассматривать отдельно, так как это не является информационной системой, а представляет собой программу для обработки и аналитики бизнес-данных. Отметим, что MS Excel применяется практически в каждой организации, но как инструмент для работы с данными. На этапе создания организации, когда число сотрудников невелико, а прибыль не позволяет принять решение о внедрении информационной системы, использование Excel весьма уместно и целесообразно. С помощью программы можно создавать такие документы, как бюджет доходов и расходов, бюджет движения денежных средств, анализировать данные за прошедший период и прогнозировать значения на последующий. Программа позволяет работать с информацией из баз данных и предоставляет простые для понимания возможности визуализации. Однако, самым большим и очень важным недостатком является невозможность одновременного доступа к работе программы нескольких сотрудни- ков, а также создания ролей для разграничения прав доступа к системе. Таким образом, не может быть обеспечена безопасность и постоянная синхронизация данных.

В таблице 1 рассмотрены элементы бизнеспроцессов, которые могут быть автоматизированы с помощью анализируемых информационных систем.

В таблице 2 рассмотрены ключевые характеристики информационных систем, которые существенно влияют на принятие решения о внедрении.

Информационные системы различаются в основном спектром встроенных возможностей аналитики, уровнем информационной безопасности и возможностью одновременного и разграниченного доступа сотрудников к системе. В зависимости от наличия или отсутствия перечисленных возможностей находится и стоимость внедрения и поддержки системы.

Таким образом, при правильном выявлении потребностей компании на определенном этапе развития есть возможность выбрать подходящую информационную систему для цифровизации и автоматизации бизнес-процессов, которая позволит сократить издержки и создать конкурентное преимущество.

Таблица 1. Сравнение возможностей информационных систем для бизнеса

\begin{tabular}{|l|c|c|c|}
\hline \multicolumn{1}{|c|}{ Возможности системы (критерии) } & «C» & «SAP» & MS Excel \\
\hline Планирование доходов и расходов & + & + & + \\
\hline $\begin{array}{l}\text { Создание аналитической отчетности по движению } \\
\text { денежных средств }\end{array}$ & + & + & + \\
\hline Учет кредитов, депозитов, займов & + & + & + \\
\hline Учет операций по эквайрингу & + & + & + \\
\hline Автоматический расчет плановых показателей & + & + & + \\
\hline Планирование прямых и косвенных затрат & - & + \\
\hline Анализ плановых и фактических затрат & + & + \\
\hline $\begin{array}{l}\text { Группировка по местам возникновения затрат (авто- } \\
\text { матически) }\end{array}$ & + & + \\
\hline Визуализация данных & + & + \\
\hline
\end{tabular}


Таблица 2. Особенности информационных систем

\begin{tabular}{|c|c|c|c|}
\hline Особенность & «1C» & «SAP» & MS Excel \\
\hline $\begin{array}{l}\text { Работа с выгрузками из } \\
\text { баз данных }\end{array}$ & + & + & + \\
\hline $\begin{array}{l}\text { Одновременный доступ } \\
\text { к системе нескольких } \\
\text { сотрудников }\end{array}$ & + & + & - \\
\hline $\begin{array}{l}\text { Создание ролей для } \\
\text { разных типов доступа } \\
\text { к системе }\end{array}$ & + & + & - \\
\hline $\begin{array}{l}\text { Интеграция с другими } \\
\text { системам }\end{array}$ & + & $\begin{array}{l}\text { В системе SAP Контрол- } \\
\text { линг (СО) и Финансы (FI) } \\
\text { являются самостоятель- } \\
\text { ными компонентами. } \\
\text { Между ними регулярно } \\
\text { выполняется обмен дан- } \\
\text { ными. Также возможна } \\
\text { интеграция с системами } \\
\text { сторонних производите- } \\
\text { лей }\end{array}$ & + \\
\hline $\begin{array}{l}\text { Наличие мобильной } \\
\text { версии }\end{array}$ & + & + & + \\
\hline Безопасность & $\begin{array}{l}\text { Может быть обеспечена } \\
\text { при правильной настрой- } \\
\text { ке системы. Постоянные } \\
\text { обновления снижают } \\
\text { степень надежности, т.к. } \\
\text { требуют переналадки } \\
\text { системы в целом }\end{array}$ & $\begin{array}{l}\text { Сертификат Британского } \\
\text { института стандартов. } \\
\text { SAР обеспечивает полную } \\
\text { конфиденциальность } \\
\text { и защиту данных потре- } \\
\text { бителей }\end{array}$ & - \\
\hline
\end{tabular}

\section{Библиографический список}

1. Выборнова Е.А., Котова К. Ю. Этапы формирования управленческой отчетности в условиях цифровизации экономики // Концепт. 2019. № 7. URL: https://cyberleninka.ru/article/n/etapy-formirovaniya-upravlencheskoyotchetnosti-v-usloviyah-tsifrovizatsii-ekonomiki (дата обращения: 26.10.2019).

2. ллычова Г.С., Хайруллин Р.P. Актуальные вопросы автоматизации управленческого учета // Бухгалтерский учет в бюджетных и некоммерческих организациях. 2016. № 9 (393). URL: https://cyberleninka.ru/article/n/ aktualnye-voprosy-avtomatizatsii-upravlencheskogo-ucheta (дата обращения: 26.10.2019).

3. https://www.sap.com/cis/products/financial-management.html

4. https://1c.ru/rus/products/products.htm

5. http://www.fingrad.com/products/management/

6. www.products.office.com

7. https://habr.com/ru/company/rtit/blog/134019/ 